\title{
How Fairy Tales Educate and Civilize Us: Ethical Literary Criticism on Fairy Tales
}

\author{
LI XIAOYI
}

\begin{abstract}
This article first discusses the history and ideology of fairy tales. As Walter Benjamin said in his essay "The Storyteller", rumors and information were spread verbally, from person to person. So were fairy tales. Through storytelling, the history and experience is spread from generation to generation. So that audience, especially children, gather to listen to the folks and stories about things "long long ago", sharing the memories and experience of the storytellers. Based on this idea, the article further analyses the utopian function of fairy tales, which depict the feasibility of utopian alternatives by means of fantastic images. Because in the name of fairy tales, anything is possible. Apart from hope and wish, there was dissatisfaction in fairy tales. Ernst Bloch placed special emphasis on dissatisfaction as a condition which ignites the utopian drive, so that it remains a powerful cultural force among the audience, urges them to resist, to change the unreasonable things in the world. At last, it comes to the ethical use of fairy tales with children. Many scholars, like Bruno Bettelheim and Julius E. Heuscher, have done some psychiatric and psychological research on the meaning and usefulness of fairy tales. Different from those, this article mainly talks about the literary education in fairy tales, how the words, characters and plots play a role in education.
\end{abstract}

Keywords: fairy tales; storyteller; utopia; education

When we talk about fairy tales, we may think of images which are related to magic or enchantments such as dwarves, giants and fairies. Everyone knows fairy tales well as they are an important part of childhood. When we want to become a King or Queen, it means we want to be the master of our own lives ontologically. In this sense, fairy tales illuminate everyone's life paths because they have existed for a millennium and have witnessed laughter and tears, gathering and parting, birth and death from generation to generation. They reflect the wish and desire deep in everyone's hearts. In other words, fairy tales have expressed people's self-change attempts and their hope for creating a better world.

Moving on to the topic of this article, how do fairy tales educate and civilize us? Apart from them being make-believe stories, fairy tales are also a reflection of the common human experience and wisdom which conveys the truths about 
life and human nature, as well as the utopian ideals which place emphasis on an ideal life and a perfect world. Never should we look down on fairy tales and simply regard them as children's literature as they apply to anyone who has not lost their child-like innocence and kindness. What we need to do is to re-explore the fairy tales and rediscover the utopian content inside the magical frames, thereafter infusing the spirit of utopia into our real life.

\section{Share Memories and Experiences by Storytelling}

When we look back upon the history of fairy tales in the context of literature, the European literary fairy tales may be described as having gone through three stages of development.

In the primary stage, fairy tales were part of mythologies and folklore. It means that from the very beginning, fairy tales were not born as a particular kind of literary genre and were not clearly defined. Literery fairy tales were preceded by the ancient Greek mythologies and some Italian folktales like The Facetious Nights (Le piacevoli notti) of Straparola and Pentamerone of Giambattista Basile.

In the next stage, people began to pay more and more attention to the folklore from the seventeenth century. Some scholars and writers who were talented and good at writing began to collect and sort the folklores and then rewrote the fairy tales based on these resources. The Perrault's fairy tales from France and the Grimm's fairy tales from Germany can be regarded as the epitome of European folktales. Works from these two countries, along with Andersen's fairy tales from Denmark, marked the birth of literary fairy tales in the modern literature form.

The last stage came with the rise of German Romantic fairy tales like Hoffmann's fairy tales. Apart from that, the rise of the English fairy tale novels can be considered as another extraordinary symbol of the maturity of literary fairy tales in the world. Especially from the mid-nineteenth century to the twentieth century, a great number of English fairy tale novels were published in the literary market and they became fairly popular and well-liked by children and teenagers. These works were diverse in style and varied in content, and most were extremely high in quality and artistic achievements, which drew attention from many parts of the world. Among them were fairy tales which became the famous literary classics of England. These fairy tales such as Alice's Adventures in Wonderland by Lewis Carroll, The Happy Prince and Other Tales by Oscar Wilde, and Peter Pan by James Barrie were widely circulated. From then on, fairy tales became an independent literary genre and generally got access to academic research. 
When we talk about the original concept of fairy tales, never can we deny the significant role they play in the passing down of shared aspects of human experience from generation to generation. Before they became literary fictions in modern sense, they were stories first of all, which we call folktales. The biggest difference between a fiction and a story is the way of creation, as fiction is created by an individual author (which is similar to the creation of the fairy tale novels of today), while a story can be a collective work of many authors and its content can be enhanced gradually along the way.

As the German saying goes, "When someone goes on a trip, he will have something to tell about". Hence, the authentic real-world experience is the foremost source of a story. The attractive plots and novel inherence in of an enduring and unfailing story comes from the defamiliarization effect which refers to the new experiences gained that are distant from people's contemporary lives.

Apart from the stories far away from home, many people also enjoy listening to local legends. It seems to be a familiar scene where people sit in a circle around a storyteller who knows the local tales and traditions well and who is willing to share the old but fascinating stories with others.

The German literary critic and philosopher Walter Benjamin once distinguished these two kinds of storytellers as the resident tiller of the soil and the trading seaman. Both ways are the origins of stories, which acquired materials from the experience far away from here and now. So that the distance in time and space accounts for the defamiliarization effect that comes from the experience.

As Walter Benjamin once said, "experience which is passed on from mouth to mouth is the source from which all storytellers have drawn" (Benjamin 1969: 84). Like folklores and stories, when the original fairy tales are being passed down from generation to generation, people are sharing their common memories and experiences which their ancestors had as well.

In "The Storyteller", Benjamin demonstrated how stories were produced, spread, and then became generally extinct in modern times. Being a genre of literary arts which inherits the epic arts, stories are inevitably spread within ethnic groups in which there are integrated and enriched with continuous experiences. Through the shared memories and experiences, people pass down the wisdom of livelihood and the meaning of life through storytelling. Storytelling does not require engaged listening, and the story itself also rejects the structures of metaphors and psychoanalysis. Therefore, the storyteller and his/her listeners always maintain a free relationship and can also build their friendship by sharing stories.

As for Benjamin himself, his memoir or prose Berlin Childhood around 1900 can be regarded as a kind of story. Taking into account its content and its way 
of narration, he is more like a storyteller who has rich experiences, abundant memories and plentiful sensibility, telling a story about childhood and city life freely and slowly. In the early 1900s, Berlin was in a period of rapid development. In twenty to thirty years, the city had undergone a fundamental reconstruction on a grand scale with numerous changes, which almost buried its history. That is to say, it was a period when traditions were fractured by modern industries and capital civilization. Faced with a fragmented world, Benjamin constructed his work with thirty separate segments rather than with continuous writing. He was trying to show the synchronic memories in non-continuous time as well as the stable things in the expanding city space. In other words, although different people spend their childhood in different cities at different times, in any given cultural context for a child, the joy and happiness to play with and read all kinds of toys and children's books, the curiosity and excitement to step into the mazelike unknown urban space, the amazement and obsession to listen to different myths and folklores, the warmth and willingness to accompany loved ones, and the earnest expectations for grand festivals and holidays, are always the same. Therefore, by fading the personal experience and sharing the common emotions and memories, Benjamin connected himself to the traditional experience with childhood writing.

Additionally, the fragmented writing format also provides Berlin Childhood around 1900 with a free relationship with its readers. The thirty passages have no continuity at all in terms of plot, time and characters. In addition, each passage is short so that readers are able to pick up the book and turn to any page to start reading at any time, as well as to close the book and continue their work conveniently. Just like a return to the traditional world of experience that has not been fragmented, people sit under the shade after working and gather to listen to the well-informed storytellers and kids sit on their elders' knees in a winter evening by the fireplace to listen to stories of the past. These stories will someday be told by the listeners to more people because the experience has constructed their common psychological foundation and makes the story sharing possible.

In this sense, we can call Berlin Childhood around 1900 a fairy tale because it also shares memories and experiences with us and reminds us of our own childhood. It tells us that even in modern civilization, as an ancient literary art form, fairy tales have never disappeared and such storytelling about childhood and innocence will last forever. 
How Fairy Tales Educate and Civilize Us: Ethical Literary Criticism on Fairy Tales

\section{The Utopian Function of Fairy Tales}

Many people enjoy reading fairy tales because they portray the belief that no matter how many setbacks and frustrations we may meet, we will eventually be able to overcome all these difficulties and lead a happy life with a bright and promising future. Just imagine, if there was a story about a brave tailor who went through an extremely hard and bitter struggle and finally defeated the evil dragon or giant but the King did not keep his promise to marry the princess to him in the end because they were from different classes, we would not call it a fairy tale. It would be considered realism. On the contrary, if a prince married an ordinary girl, we would admire the story and consider it as a true fairy tale. Such opposite attitudes result from the different expectations of fairy tales and the real world. The element in fairy tales that inspires people to pursue an ideal life and a perfect world can be called the utopian drive.

A utopia is an imagined and ideal community or society that possesses highly desirable or nearly perfect socio-political-legal system. The term utopia was coined in Greek by Thomas More for his 1516 book Utopia, describing a fictional island society in the Atlantic Ocean. This word comes from the Greek and means "no-place", and strictly describes any non-existent society. Perhaps many people are familiar with this term because of the German Marxist philosopher Ernst Bloch's book The Spirit of Utopia. It is considered that in the Chinese context, utopia consists of three meanings: 1) airy-fairy, unscientific, and impractical; 2) combined with socialism to distinguish from scientific socialism; 3) a literary genre like fantasy fictions (Chen Anying 2001: 130). Instead of airy-fairy, unscientific or impractical, Bloch used the term in a more abundant sense as the concept of not-yet and hope, thus remodeling practicality for utopia.

Bloch devoted himself to discovering the human potential of struggling for a better world, which constitutes the principle of hope and shows the possibility of humans being the creators of history. In his philosophical works, he frequently mentioned folklores and fairy tales, which made up his philosophical foundation. He once wrote a short essay, The Fairy Tale Moves on Its Own in Time in 1930. In this essay, he mentioned that "the fairy tale narrates a wish-fulfillment which is not bound by its own time and the apparel of its contents... One can also find the demons of old times, who return in the present as economic ogres. The political strategy of the leading 200 families is fate." (Bloch 1998:167) In this sense, although the feudal society that helps to create the atmosphere of traditional fairy tales is gone, the contradictions which give rise to fairy tales still exist. People today still meet with might and injustice, and still long for love, wealth and happiness. Hence, their desires for an ideal world, or, to put it in another way, their utopian drive will not disappear, and fairy tales will last 
long. This is the reason why even in a young country that has not experienced the feudal society or transition period, Walt Disney's fairy tales can still revive the old fairy tale traditions and move millions of people today.

Fairy tales can always mirror our dissatisfactions and wish-projections. We all know the youngest child Hans who was thought to be foolish but finally succeeded in marrying the princess, or the poor soldier who got a tinder-box from an old witch and finally became rich. Bloch noted that in a fairy tale, the protagonist is always the underdog, the youngest child and the most deprived, or to say the most discontented. Fairy tales do not only show the narrators' and audiences' best hopes and wishes, but also thrive on their deepest disappointment and dissatisfaction. From his point of view, such dissatisfaction and discontent is the principal element that leads to the utopian drive. As an anticipated illusion art, fairy tales can bring out people daydreams, which help to accelerate actions and hopes for change. Such daydreams related to an ideal world can be regarded as the potential state of being. The meaning that such symbolic art can reveal weighs more than itself, and the significance of fairy tales comes from their promotion for society.

Like other kinds of art, fairy tales do not directly reflect all the truths in a metaphysical way. On the contrary, they contain a presupposed hypothetical structure of the not-yet achievements. The Not-Yet-Conscious is a very important cornerstone of Bloch's philosophy. As early as 1907, he had pondered on this issue and wrote an essay On Not-Yet-Conscious. Later in The Spirit of Utopia, he also talked about On the Metaphysics of Our Darkness, of the NoLonger-Conscious, the Not-Yet-Conscious, and the Inconstruable We-Problem. Be it his early philosophical discussion or his construction of utopian philosophy later on, the concept of Not-Yet is the key factor that connects his philosophy of hope, utopia and Marxism. He considered hope as an ontology and described Not-Yet as a process, and advocated the spirit of utopia, and then claimed to create a better future. He once wrote in the introduction of The Principle of Hope that "the Not-Yet-Conscious in man belongs completely to the Not-Yet-Become, NotYet-Brought-Out, Manifested-Out in the world. Not-Yet-Conscious interacts and reciprocates with Not-Yet-Become, more specifically with what is approaching in history and in the world. And the examination of anticipatory consciousness must fundamentally serve to make comprehensible the actual reflections which now follow, in fact depictions of the wished-for, the anticipated better life, in psychological and material terms. From the anticipatory, therefore, knowledge is to be gained on the basis of an ontology of the Not-Yet" (Bloch 1986:13). Fairy tales in this sense can also be regarded as Not-Yet-Conscious because they give the discontented people hopes about a promising future. There are evil demons and arduous challenges, but they are all just a process and justice will eventually 
How Fairy Tales Educate and Civilize Us: Ethical Literary Criticism on Fairy Tales

defeat evil, bringing a brighter future. With the utopian drive gained from the fairy tales, people can break through brambles and thorns and overcome all obstacles to fight for a better world and better future. That is how fairy tales transfer the utopian drive to practical activities, and also the reason why we can always gain courage and strength from fairy tales whenever we feel frustrated.

\section{The Ethical Use of Fairy Tales with Children}

Many scholars have done psychiatric and psychological research on the meaning and usefulness of fairy tales. For instance, Julius E. Heuscher, who has written A Psychiatric Study of Myths and Fairy Tales; Their Origin, Meaning, and Usefulness, concentrated his research on the different methods for analyzing fairy tales and finding various themes that run through many tales. He also explored the meaning of folklore and fairy tales and their usefulness in education and psychotherapy. Another example is the Austrian-born American child psychologist Bruno Bettelheim. Bettelheim once wrote The Uses of Enchantment: The Meaning and Importance of Fairy Tales, which applied Freudian psychology to fairy tales and won many national awards. Although Bettelheim is a controversial figure because of his personal experience and some of his theories have been considered to be thoroughly discredited currently, we should not deny his contribution to the study of fairy tales and look down on the significance of his book The Uses of Enchantment. In his opinion, "fairy tales have unequaled value, because they offer new dimensions to the child's imagination which would be impossible for him to discover as truly on his own", and "the form and structure of fairy tales suggest images to the child by which he can structure his daydreams and with them give better direction to his life" (Bettelheim 1977:7). In other words, from the perspective of psychoanalysis, fairy tales can liberate children's subconsciousness and help them discover and understand their intrapsychic conflicts, which may cause psychological distress if they are repressed. Bettelheim believed that since fairy tales present the living predicament in a direct way, children are able to understand the inner conflicts of characters as well as themselves and hence are able to gain imagination and courage from most fairy tales and learn to behave properly when they are faced with the dilemma during their growing up stage. Probably Bettelheim had exaggerated the Psychotherapeutical use of fairy tales and placed too much psychological significance on them in order to verify his theory. Nevertheless, we can take his research only as a reference and focus more on the ethical use and literary significance of fairy tales. 
Since fairy tales first developed from mythologies and folklores, many fairy tales that were collected and rewritten by folklorists and writers would be very similar to the folklores both in structure and motif. Many fairy tales tend to take a ternary form which will repeat the similar core plot two or three times. For example, in Snow White, the evil Queen would ask her magic mirror for three times, "Mirror, mirror on the wall, who is the fairest of all?" By the third time, the mirror would answer that it is Snow White. Hence, the Queen decided to kill Snow White by asking a Hunter to kill her. However, she later found out that the hunter had betrayed her. Therefore, she disguised herself as an old peddler for three times and sold colorful laces, a poisoned comb and a poisoned apple to Snow White. Such a three-section structure is just like the three-part musical form. Many ancient folklores and legends are spread by songs and among them, many are sung in a three-section form, for example, the folk songs of the Yi nationality in China. The advantage of such a structure is apparent because through repetition, the audience will be familiar with the plot and will be able to remember it easily. Also, when it is repeated for the third time with a tiny but crucial shift compared with the previous two times, it will create an element of surprise and wonder. This form is frequently adopted especially in verbal art.

Similar to mythology and folklores, many fairy tales have the same motif patterns. A motif can be any basic narrative element that appears once and again in different stories, like an object (a wand), a fantastic animal (a talking horse), a concept (a taboo), a behavior (a test or cheat), or a character type (a fool or a prophet). For example, we all know Cinderella, but there is also a Chinese Cinderella called Ye Xian (Yeh-Shen), which is recorded in the Tang dynasty about 1200 years ago. In that story, Ye Xian got a fantastic fish but it was eaten in secret by her evil stepmother. Ye Xian buried the fishbone and every time she prayed to it, she was able to get whatever she wanted. Ye Xian dressed up beautifully during a festival with the bone's help but carelessly left behind one of her golden slippers. The King wanted to find the owner of this tiny beautiful slipper and asked all the women to come forth to try on the shoe and it only fit Ye Xian perfectly. With that, she married the King. With the motif of shoe trying, we can say that Ye Xian and Cinderella have the same motif pattern. The American folklorist Stith Thompson, who wrote Motif-Index of Folk-Literature: A Classification of Narrative Elements in Folktales, Ballads, Myths, Fables, Medieval Romances, Exempla, Fabliaus, Jestbooks, and Local Legends, developed an alphadecimal motif-index system called the Aarne-Thompson classification systems, which we can retrieve and refer to in order to understand the motifs children can learn to compare and classify as well as recreate with these elements.

Apart from their the structure and motif, fairy tales are also known by their fantastic content, magnificent imagination and funny details. Fairy tales seem to 
How Fairy Tales Educate and Civilize Us: Ethical Literary Criticism on Fairy Tales

be animistic and regard everything as alive or inhabited by a spirit. It is normal to find an animal, a plant or even an object that can talk or have magical powers in fairy tales. Inspired and edified by such fantastic stories, children are likely to be more creative and have the ability to invent the future with great imagination. Moreover, they may become sympathetic and kindhearted because the fairy tales teach them to respect everyone and everything. In addition, as mentioned earlier, the plot of fairy tales often starts off with challenges appearing, figures feeling discontented and engaging in struggle, solving crises and achieving their goals and eventually ending off with a happy ending. It provides children with optimism and positive values that enable them to stay hopeful during difficult times and convinces them that justice will triumph over evil.

Instead of living unrealistically, people who grow up with fairy tales tend to believe in the wonder and beauty of life as well as respect life, which also brings them optimism and strength to overcome challenges in life.

\author{
Li Xiaoyi \\ lixiaoyi11@pku.edu.cn \\ Room No.534, Building 3, Changchunxinyuan \\ Peking University \\ No.5 of Yi He Yuan Road \\ Haidian District, Beijing, 100871 \\ CHINA
}

\title{
References
}

Benjamin, W. 1969. Illuminations: Essays and Reflections. New York: Schocken Books. Bettelheim, B. 1977. The Uses of Enchantment: The Meaning and Importance of Fairy Tales. New York: Random House.

Bloch, E. 1998. Literary Essays. California: Stanford University Press.

Bloch, E. 1986. The Principle of Hope (Volume One). Cambridge: The MIT Press.

Chen, A. 2001. Research on the Transformation of the Meaning and Concept of "Utopia”. - Journal of Peking University (Philosophy \& Social Science), 1, 123-131. 